\title{
SUMMER BOOKS
}

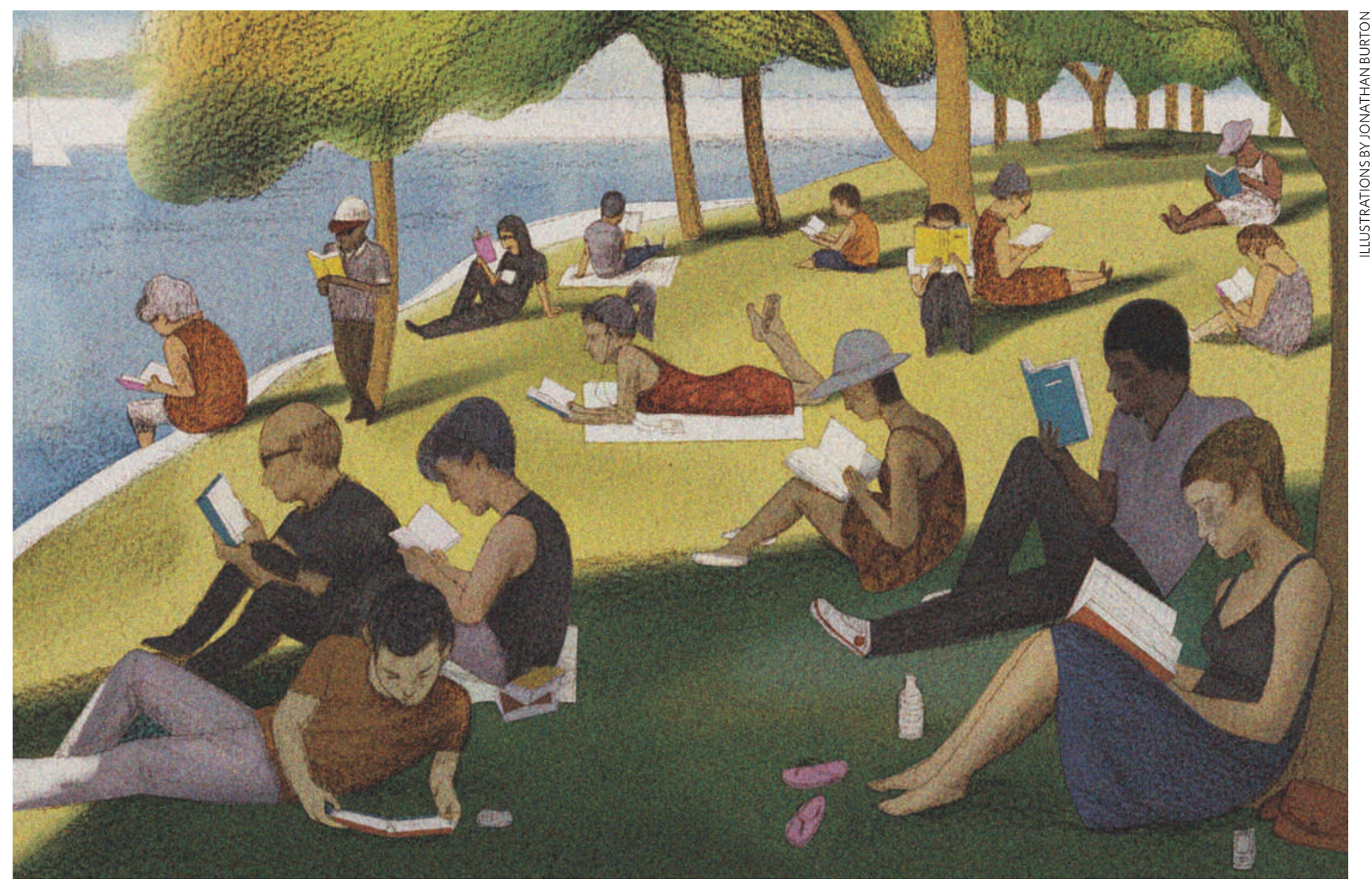

\section{A break from the bench}

Nature regulars give their recommendations for relaxed, inspiring holiday reading and viewing — from climate-change history to Isaac Newton the detective.

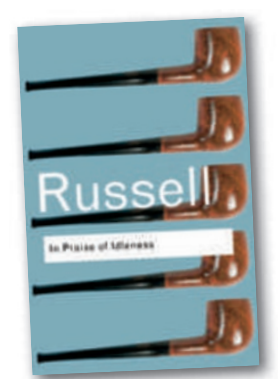

DAVID POEPPEL In Praise of Idleness: And Other Essays by Bertrand Russell Routledge Classics: 2004.

Many academics in the United States will have spent the past few months frenetically applying for support from the sudden infusion of research funds made available by Barack Obama's administration. Now, the over-stimulation of the stimulus package should be balanced with a break from the academy - with philosopher Bertrand Russell.

His essay In Praise of Idleness, written in 1932 and published with a group of works on modern life, reflects the delicate balance between frivolity and gravitas that is characteristic of his writing. As well as giving insightful arguments in favour of relaxation, his short pieces are politically edgy. Reading Russell is pure pleasure: just the right mixture of fun, provocation and raw insight. Reading this book on the beach or in a hammock will feel like winning a small moral victory.

David Poeppel is a professor in the Department of Psychology at New York University, New York.

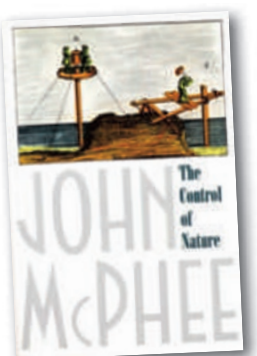

\section{MIKE BROWN}

The Control of Nature

by John McPhee

Farrar, Straus and Giroux: 1990.

After I built a small retaining wall last year to prevent my back yard from tumbling into the canyon below, I reread The Con-

trol of Nature, John McPhee's exploration of human attempts and failures to dominate the natural world. Adding to my delight, these engrossing stories about geological catastrophes in distant places can now be transformed into a visceral confrontation with the real world by looking up the locations on Google Earth. You can track the paths of debris flows from the San Gabriel Mountains in Los Angeles, follow the convolutions of the Mississippi River and view the now-hardened Icelandic basalt — making you realize that these things really happened, right here.

But you don't need a computer to relish passages such as the opening of 'Los Angeles Against the Mountains', in which viscous mud quickly fills a house and presses an apparently doomed family against the ceiling. I know how that story ends, but every time I finish it I find my heart racing and my fingernails missing. And then I walk outside, look at my retaining wall, and add another rock or two.

Mike Brown is a professor of planetary astronomy at the California Institute of Technology, Pasadena. 


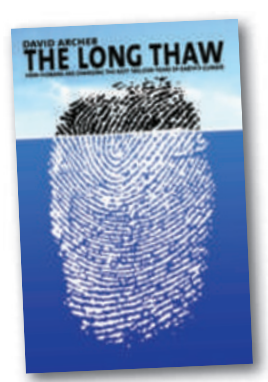

\section{SUSAN SOLOMON \\ The Long Thaw: How \\ Humans Are Changing the Next 100,000 Years of Earth's Climate by David Archer Princeton University Press: 2008.}

A hot summer is the perfect time to learn about climate change and carbon with this enjoyable and fast-paced treatise. Delve into The Long Thaw to contemplate how the actions and decisions being made now will affect our climate - not just in our lifetimes but for many millennia. David Archer masterfully sweeps through climate-change history and reviews the intricate cycling of carbon dioxide through the atmosphere, biosphere and ocean.

I have searched long and hard for an easily understandable description of ocean acidification, weathering and the enduring impact of humans on Earth's climate and carbon, and this book delivers on each of these challenges in a compelling way. It is comprehensive, well written and includes numerous useful vignettes from climate history. Archer leads the reader to a simple yet accurate picture of climate changes, ranging from geological time scales to current warming, ice ages and prospects for the future.

Susan Solomon is senior scientist at the Earth System Research Laboratory of the National Oceanic and Atmospheric Administration in Boulder, Colorado.

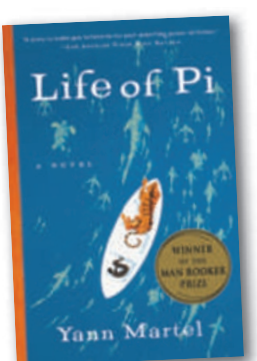

JERRY A. COYNE Life of Pi

by Yann Martel

Houghton Mifflin

Harcourt: 2002.

As I grow older, I find myself consuming much more nonfiction than fiction: there is so much to learn about the world before we leave it. But one book, Life of Pi by Yann Martel, stands out. It is the fantasy tale of a zookeeper's son, an Indian boy named Pi Patel. The ship transporting the Patels and their menagerie to Canada founders, leaving $\mathrm{Pi}$ in a lifeboat, his only companion a hungry Bengal tiger named Richard Parker.

Their story of survival amid mutual distrust and dependence is an engrossing drama, limned by ruminations about life, faith and the nature of reality. The story is also deeply informed by knowledge of animal behaviour that will appeal to biologists. Pi's defence of zoos, for example, is a masterpiece of argument. A powerful piece of magical realism, Life of $P i$ is a worthy successor to Salman Rushdie's Midnight's Children and Gabriel García Márquez's One Hundred Years of Solitude.

Jerry A. Coyne is a professor in the Department of Ecology and Evolution at the University of Chicago, Illinois.

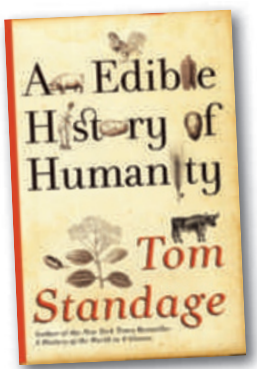

\section{MING-WEI WANG An Edible History of Humanity} by Tom Standage Walker \& Company: 2009

"Bread is the staff of life" is an ancient saying. Yet most people never think of the effect that food has had on the history of humankind. Tom Standage's An Edible History of Humanity does so comprehensively using historical and analytical approaches (see also J. Hoffman Nature 459, 912-913; 2009). The influence of food production and distribution on social change, political organization, geographical competition, industrial development, military conflict and economic expansion are likened to "an invisible fork that has, at several crucial points in history, prodded humanity and alerted its destiny".

Food is closely linked with the advancement of science and technology: "the adoption of agriculture is the tale of how ancient genetic

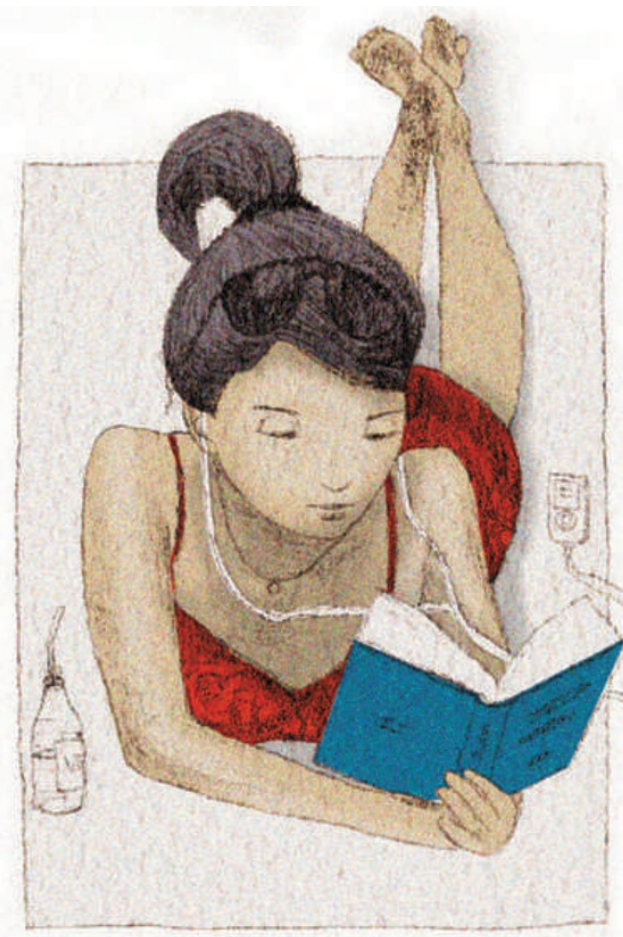

engineers developed powerful new tools that made civilization itself possible. In the process, mankind changed plants, and those plants in turn transformed mankind." Standage provides a thorough perspective that includes the genetically modified organisms of today, the relationship between food and poverty, the production of biofuels and the environmental impact of modern agriculture.

Ming-Wei Wang is director of the National Center for Drug Screening, Shanghai, China.

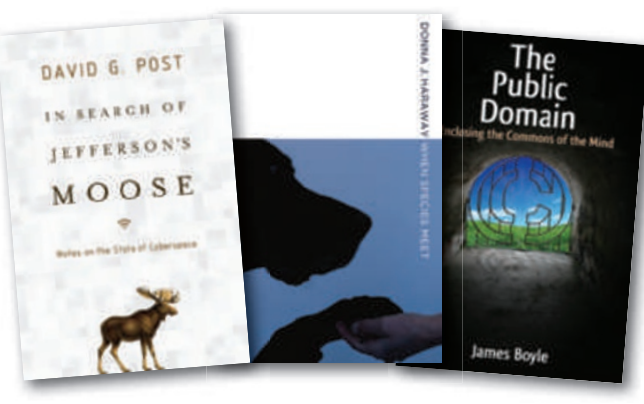

\section{JONATHAN ZITTRAIN}

In Search of Jefferson's Moose: Notes on the State of Cyberspace

by David Post

Oxford University Press: 2009

When Species Meet

by Donna Haraway

University of Minnesota Press: 2007.

The Public Domain: Enclosing the Commons of the Mind

by James Boyle

Yale University Press: 2008

David Post, Donna Haraway and James Boyle each offers insight into rapidly evolving relationships - among people, ideas and also animals. Post provides a vision of cyberspace through the prism of Thomas Jefferson, the American statesman and polymath who brought a moose to Paris to demonstrate just how different the New World was. To Post, the distributed nature of cyberspace opens up a sense of possibility that is well-mirrored by the frontiers of the late eighteenth century. He laments the idea that borders may eventually carve up this Internetworked space, in ways different from the borders that naturally arise from self-organizing online communities.

'Posthumanities' expert Haraway also concerns herself with unnecessary borders: those that she thinks humans have wrongly established between themselves and other species, particularly domesticated companion species. She explores the blurring of the lines between human and machine, real and virtual, natural and artificial.

Add to this Boyle's definitive work on the public domain, and one can see in common a 
deep and spirited paean to 'remix' - a desire for legal, technical, economic and cultural architectures that permit ideas to flow freely from one mind to another, being reshaped in unexpected ways as they go. Boyle's call for digital literacy resonates with Post and Haraway's urging for us to see what is in front of us in a new light. And each draws beautifully on how things used to be to point the way forwards.

Jonathan Zittrain is a professor at Harvard Law School and co-founder of the Berkman Center for Internet \& Society, Cambridge, Massachusetts.

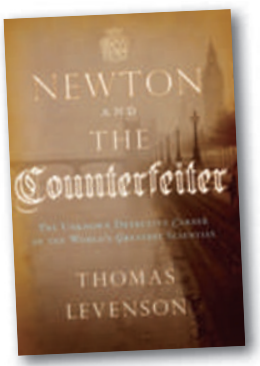

CARL ZIMMER
Newton and the
Counterfeiter:
The Unknown
Detective
Career of the
World's Greatest
Scientist
by Thomas
Levenson

Houghton Mifflin Harcourt: 2009.

Imagine Isaac Newton as a policeman, using his brilliant intellect to pursue the most elusive thieves of his day. It sounds like a ridiculous example of historical fiction - except that it actually happened. In Newton and the Counterfeiter, Thomas Levenson recounts how Newton became Warden of the Royal Mint and pursued a master forger, William Chaloner. Levenson's account of the struggle between these two masterminds is fascinating on its own, but he also uses this historical episode to show how the modern economy took shape in the late 1600 s.

The book's resonance with today's economic upheavals seems almost too good to be true. Would you believe that Isaac Newton lost much of his fortune in a financial crash? The physicists whose models of financial risk lie in ruins today can take some comfort in Levenson's stranger-than-fiction tale.

Carl Zimmer is a writer based in Connecticut.

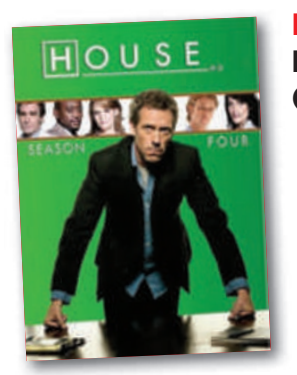

FELICE FRANKEL House, M.D. (Season 4 DVD) Episode 15 ('House's Head') directed by Greg Yaitanes; Episode 16 ('Wilson's Heart') directed by Katie Jacobs

Written by David Shore, Peter Blake, David Foster, Russel Friend, Garrett Lerner and Doris Egan

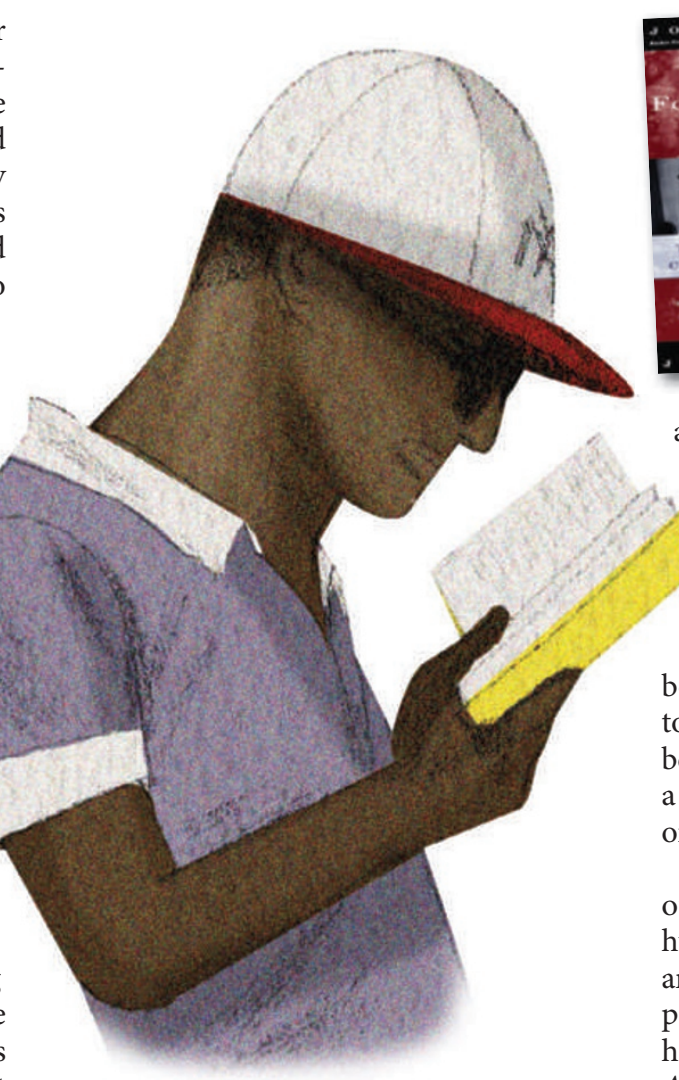

Put aside your preconception that insightful storytelling never emanates from Hollywood; insert the DVD for season 4 of House, M.D. into your computer; and forward it to episode 15. For three-quarters of an hour, you will be engrossed in a mystery with scientifically and medically accurate twists and turns - and will then be compelled to watch episode 16 for the resolution. The interconnected plot of these episodes emphasizes the fragility of our lives and how one simple 'mistake' can change everything. You will witness mesmerizing directing and superb acting.

My concern in recommending only these two episodes is that you will not experience the full pleasure of watching Dr Gregory House, played by Hugh Laurie with deprecating wit and brilliance, nor the intelligent development of the relationships between the characters over the years, nor House's subtly uproarious insights into his colleagues, patients and the human condition - such as "everybody lies". For that, you will have to watch the complete series, which I am not embarrassed to admit I own.

Felice Frankel is a senior research fellow in the Faculty of Arts and Sciences at Harvard University and a research scientist at the Massachusetts Institute of Technology, Cambridge, Massachusetts.

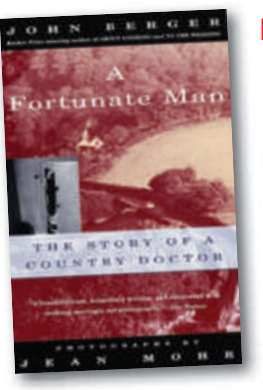

HUGH YOUNG

RIENHOFF

A Fortunate Man: The Story of a Country Doctor by John Berger

Vintage: 1997. First published by Holt, Rinehart and Winston: 1967.

I am reading John Berger's A Fortunate Man again. An anthropologist, Berger manages to inhabit the skin of real-life physician John Sassall and at once take the pulse of his English villagers, society and the human condition. Berger is an invisible presence, documenting the inner and outer life of a man with a conflicted dedication to both science and human need. While tending to births, to the dying and to the suffering in between, Sassall concludes that illness has both a real and imagined component. Sickness is organic and psychic, one leading to the other.

Sassall confronts the plain facts of life without apparent argument. He is a witness to humanity's desperation and terrible loneliness and treats what he can. Sassall's devotion to his patients, his energy and his competence earn him the privilege of trust he uses so carefully. A Fortunate Man is not merely the best book written about a general practitioner, it teaches physicians about humanity and humility. Ultimately, it teaches the rest of us that inhumanity is society's greatest sickness.

Hugh Young Rienhoff is director of MyDaughtersDNA.org, based in San Francisco, California.

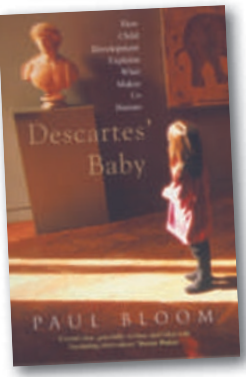

BRUCE HOOD Descartes' Baby: How Child Development Explains What Makes Us Human

by Paul Bloom

Arrow Books: 2005. First published by William

Heinemann: 2004.

From the opening line, "Having sex with dead animals is disgusting”, I knew Descartes' Baby was going to be a fun read. Paul Bloom explores the human condition by following the turbulent voyage of a child's mind during development. Arguing that the infant brain is configured to interpret the world in terms of objects and people, and subsequently bodies and minds, he arrives at the mind-body dualism that philosopher René Descartes pondered - a solution that modern neuroscience has rejected. 
This is the first popular book to articulate the emerging scientific interest in the idea that dualism of the material and immaterial world leads humans to naturally infer a deeper underlying reality. Such a belief system explains many of our attitudes and preferences to issues as diverse as sex, love, eating and organ transplantation. Descartes' Baby is a powerful book that tackles fundamental aspects of the human mind in an accessible style.

Bruce Hood is a professor in the Department of Experimental Psychology at the University of Bristol, Bristol, UK.

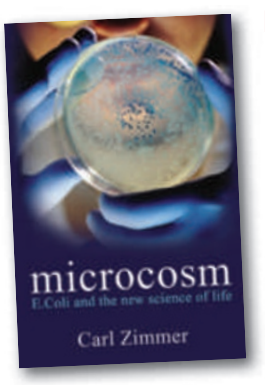

NEIL SHUBIN

Microcosm: E. coli and the New Science of Life by Carl Zimmer

William Heinemann/ Pantheon Books: 2008. What is life? Why do creatures cooperate? Why do living things die? Carl Zimmer, a leading writer on evolution, finds answers to these and other big questions in the most humble of places - the common gut microbe, Escherichia coli. In Zimmer's hands, E. coli becomes a window on to the basic properties of life and the ways that complex living systems can arise and change.

Zimmer weaves a narrative through the main principles of evolution, genetics and ageing, with stories of the people who made major breakthroughs along the way. His simple way of explaining complex ideas and his fast storytelling pace make for delightful reading. Each chapter contains 'wow' moments about bacteria and the joys and travails of the scientists who study them. The result is a scientific detective story that left me with a new appreciation of the trillions of microbes that live on and inside my body.

Neil Shubin is professor of anatomy at the University of Chicago, Illinois.

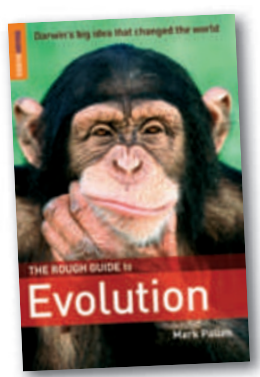

EUGENIE SCOTT The Rough Guide to Evolution by Mark Pallen Rough Guides: 2009 The 200th anniversary of Charles Darwin's birth, plus the 150th anniversary of the publication of his best-known book, On the Origin of Species, make 2009 the year to learn about evolution.
Mark Pallen's The Rough Guide to Evolution provides a concise summary of what you need to know: a brief history of the idea that all living things share common ancestry, a complete survey of the mechanisms of evolution and a solid summary of how life originated and then adapted through time to a changing planet. He livens up the story with literary, musical and cultural references so that you never feel you are being told to eat your vegetables. Alas, it is not only non-specialists who don't have a firm grasp of the strength of theory and data supporting the modern understanding of evolution - many scientists outside the field of evolutionary biology struggle too. This entertaining handbook will bring anyone up to date.

Eugenie Scott is executive director of the National Center for Science Education, Oakland, California.

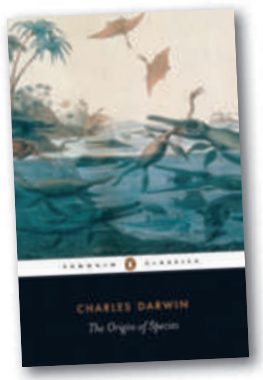

SANDRA KNAPP On the Origin of Species by Means of Natural Selection

by Charles Darwin

Penguin Classics: 2009.

First published by John

Murray: 1859.

On the Origin of Species is the crystallization on paper of what is arguably biology's biggest
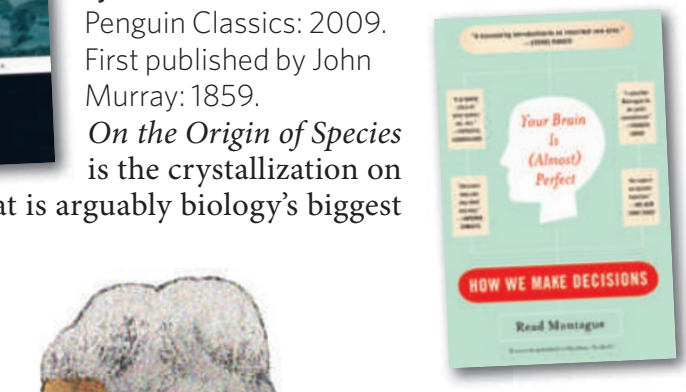

ADAM KEPECS Your Brain Is (Almost) Perfect: How We Make Decisions by Read Montague Plume (Penguin): 2007. Read Montague brings together neuroscience, psychology and computer science to explain how brains function as efficient computational machines. He first looks at the brain as a physical device, exploring how this energy-efficient information-processing system evolved out of slow and noisy biological components. Montague argues that it is the valuation system that makes brains different from computers, allowing brains to compare disparate options and to 'care' about different goals. Montague elegantly weaves a radical outline of how brains make decisions and ultimately produce the mind.

It is refreshing to read an intelligent book that bucks the trend of many popular expositions of science that simply recount a series of anecdotes, often to the exclusion of deep ideas. This original and clearly written contribution may not be an easy read, but its insights are well worth the effort.

Adam Kepecs is assistant professor of neuroscience at Cold Spring Harbor Laboratory, New York. 